\title{
THE NEED OF EDUCATION IN THE FIELD OF DOMESTIC VIOLENCE
}

\author{
Peter Papáček \\ Pan European university, Slovakia
}

\begin{abstract}
The paper deals with the thesis that our classical type of education is not always enough to prepare us for the real life matters. One of those matters, a really negative one, is the domestic violence. It is a not very comfortable issue to talk about or to admit its existence in our lives. Furthermore, it deals with the possibility to find a place for this education issue in our educational system and its curriculums. The main aim is to prepare and to give the knowledge about the matter of domestic violence to the youngsters at a reasonable age. It could help in the field of prevention and even in the situations when we have to face the domestic violence - to identify its forms, what can the legal consequences be, how can we act, how can the legal authorities help, what are their competences and how or where can we get legal aid. The paper uses mainly analytical methods to examine the current state and comparative methods too, to compare the current state and the status recommended by the aim of the paper. The main research result is an educational model in the field of domestic violence which is practical and useful in real life situations.
\end{abstract}

Keywords: education, domestic violence, prevention, victimization

\section{Introduction}

Domestic violence is a very significant negative phenomenon of our society. In fact, this phenomenon is as old as the humanity itself so in our opinion we can state that we could not find any efficient way to fight against it. The key of its elimination could be hidden in the factors of aggressive behaviour in a family and its origins. While this issue is not eliminated from our society one of the best ways to fight against it is to study this phenomenon, learn about it and in case of need to be ready to act swift and smart. According to our real life experiences it is easier to face some problems if we have a knowledge about the issue we have to face. The education in this field from a proper age could play an important role in our preparation for the real life situations like those mentioned above. In our opinion the lexical form of knowledge and form of education is nowadays not the most important one. A place in the educational system related to some really important real life issues in a long term perspective could help our society to improve. We do not mean only the issues related to the domestic violence, but for example even the importance of the elections. If we are not educated enough to understand the 
importance of an election and we ignore it, than it is a nice example of fulfilling the will of a minority for a whole country which does not have to reflect the nation's majority will. We can also find some connection between the education and the domestic violence in both perspectives, the perspective of the aggressor and the perspective of the victim. For example the right education can make understand the aggressor that the role of a man (male aggressor) in the family is not about his dominance and physical enforcing of his will and the victim that his/her submission is not natural and he/she has to suffer without taking any steps against this behaviour. Taking in consideration the above mentioned thoughts the main aim of our research is to analyse the possible effects of education in the field of domestic violence on the aggressor's and the victim's behaviour in the situations connected to domestic violence.

\section{Domestic Violence and Its Meaning}

If we deal with domestic violence it is important to explain what we exactly mean. At first sight it seems to be easy to explain, but it is a key question what exactly the domestic violence is and when are some types of behaviour crossing a line of accepted forms of behaviour in the society. In the field of law and prevention it is essential to answer this question. Domestic violence is a complex of difficult relations which have various character, intensity and nature. The subjects of domestic violence could be close or distant relatives, opposite genders or in different age categories. An important role plays the geographical location of the society and its level of development. In the countries of the third world or Islamic countries the traditional forms of domestic violence are significant physical, psychical or sexual violence. For the countries which are economically well developed the modern forms of domestic violence are typical - social violence, economic control or isolation. This variability of domestic violence makes it hard to properly define, but on the other hand its definition would help to choose the effective tools for its suppress and elimination. It means while we can not exactly state what the domestic violence is, we can not efficiently fight against this phenomenon (Noughani \& Mohtashami, 2011). For example there are numerous researches in the field of domestic violence which revel that every third or fifth woman is a victim of domestic violence, but in the lack of globally accepted limits of domestic violence, we do not know what actions or behaviours do they subsume under the expression ,domestic violence”. Among those numerous researches even an interesting link was fount between the domestic violence and the animal cruelty (Faver \& Strand, 2003). In our opinion a common mistake is also the focusing only on one group of victims - women. Without any doubt they are the most frequent victims of domestic violence, but also the children, seniors and disabled deserve an attention. In fact the first international 
and European documents dealt with domestic violence also only with the women in their focus, but in the last decade it started to change (Tittlová, 2016).

As we mentioned above, the forms of domestic violence can be understood in two ways:

1) the classical - physical violence, psychical violence, sexual violence,

2) the modern - social control, isolation, economic control.

The exact definition of domestic violence complicates different problems which are connected to (Tittlová, 2017):

- the great diversity of domestic violence (different forms and manifestation),

- the narrow understanding of domestic violence (only women as victims),

- the different interpretation of various terms (what is family, close relation, home, etc.),

- $\quad$ the widening of key signs of domestic violence (e.g.: from home to the public or to work),

- $\quad$ the different perception of domestic violence in an international level.

According to assistant professor Tittlová the definition of domestic violence is more preferable to sense from the perspective of unchangeable contents which should not miss in any of the actions which can be characterised as domestic violence. According to her we can consider as unchangeable contents the following features (Tittlová, 2017):

- close relations, intimacy in the relations (in families, close relationships, emotionally shaded),

- $\quad$ living in a common household (the aggressor and the victim usually share a house),

- connectivity between the aggressor and the victim (the common living and the filiation makes automatically a bind),

- continuity (the attacks are frequent and we can not talk about one attack),

- $\quad$ recurring attacks (the periods between the attacks are getting always shorter),

- the growth of aggression and intensity of the violence (at first the violence is not so intensive, but it starts to escalate),

- difficult revelation of the domestic violence (nowadays the domestic violence can be detected even in public, but typically it happens at home without witnesses),

- imbalance in the relationships (the aggressor's dominance and the victim's submission), 
- continuation (somehow the victims are often not able to exist without the aggressor and they find a way back to him/her).

\section{Victimization}

Primary victimization is connected to the primary consequences of the crime caused by the perpetrator. Secondary victimization is causing secondary harm to the victim by professionals (police officers, doctors, experts, etc.), family members or close social environment. It is important to remember that secondary victimization can be only done to ,official” victims in criminal proceedings and to latent victims not, because the state authorities does not even know what happened. So the secondary victimization is not a direct consequence of the offense, but a reaction to the behaviour of institutions and individuals towards the victim. The law enforcement agencies are one of the first to get in touch with the victim directly after the offense, so they have the highest chance to cause a secondary victimization. If they cause the secondary victimization it does not have to be only their fault, because in numerous cases the professionals during their career does not get the proper preparation or education to face issues like this (Tower, 2003). With the aim of reducing the stress and prevent secondary victimization, mainly in cases where children are involved, there is a need of a special room for the hearings of the witnesses. The importance of protection of the minors in hearings as witnesses is also reflected in the judgement of the Court of Justice in case C - 105/03 - Pupino (Klimek, 2017). Another relevant source of secondary victimization is the victim's family and friends. One of the most important development trend in the area of assistance to victims are „the institutions assisting victims". The role of these institutions are brittle, because a very relevant moment is when and how they try to assist to the victim. Why is it important? If we put ourselves in the role of the victim it is unlikely that we start to browse on the internet for some institutions like the above mentioned, so the most important step depends on them to offer their help (Strémy \& Jurisová, 2017).

At this point we have to mention the mediation and the role of the mediator. We want to point out the fact that interdisciplinary approach to his work, as a mediator of resolving interpersonal conflicts in an out-of-court way, is the appropriate action field for the social worker and the social pedagogue in particular while manifestations of domestic violence (Svoboda, 2017). The quality of their work depends even on their level of education, so it is unfolding from the educational system and the quality what universities can give (Danis \& Lockhart, 2003).

An important role has the victim to announce the violence to the state authorities because only in a few cases happen that other institutes like hospitals 
or schools does it instead of them. We have to keep in mind that to announce the violence is important in time because as the time passes it is more difficult to prove it. Late announcements are frequent because of feeling ashamed and the ignorance of the victim what will happen after the announcement. It is the reason why we have to be educated in the field of domestic violence, to know what are or legal options and how can the state authorities help and what can be the consequences for the aggressor. On the other hand the education in this area is also very important for the state authorities because they are the first one to get in touch with the victims and the cooperation with them after the violence in their unstable psychical condition is very complicated and it needs special approach. Neglecting such an approach can lead to secondary victimization.

\section{Expulsion from the common dwelling}

One of the most known measure of prevention against domestic violence is the expulsion from the common dwelling. To know the specifies of this measure is important both for the aggressor and the victim. Very important feature is that this measure can be applied only by fulfilling the conditions prescribed by the law (Act No. 171/1993 on the police corps). and strictly within the specified range of the law. If this measure is not applied in accordance with the above mentioned than it will cause liability for damage caused by the exercise of public authority. The essential condition for applying this measure is that we can expect the violence from the aggressor in the common dwelling - attack on life, health, human dignity, etc., especially with regard to former attacks. According to the Slovak legislation for applying this measure some facts of threat of attack must be plausibly found. The police officer is examining the situation on the spot and he must come to a conclusion that an attack can be expected in a short time. It is very important to note the fact that the police officer has the authorization to apply this preventive measure, but it is not his duty to apply. It means that the application depends on the objective findings of the police officer and the threatened person does not have a legal claim for the realisation of the expulsion. The expulsion interferes with fundamental rights and freedoms of an individual so its duration is limited by the law. It is difficult to find an optimal length which is not too short, but even not too long. According to the valid Slovak legislation the expulsion can be applied for 10 days. The time limit is based on days and not on hours like it was before and in our opinion it is advantageous for the threatened person what is positive. The first day is always the day after the expulsion. At this point we have to mention that this legal act of the police officer, the expulsion, shall come into force from the moment of its demonstrable declaration. It means that the relevant moment is the personal knowledge of the aggressor about the legal act and the decision shall take effect from the moment of his knowledge about that act. It is a 
statutory time limit which means no subject can shorten it. Its prolongation under certain circumstances is possible.

The expulsion can be considered as an immediate procedure and from the moment of its notification the aggressor is in the position of obligated person. This means that he/she will incur several obligations. One of these obligations are to leave the area stated by the police officer immediately and it has an unconditional character - without conditions like he/she will leave this area only in the presence of his/her lawyer or only after securing an alternative living for him/her. Based on the valid Slovak legislation the obligated person has to hand over the keys and also the spare ones. In case of not fulfilling this obligation a penalty up to $100 €$ could be given. During the 10 days of expulsion the aggressor is obliged to stay outside the area stated by the police officer. Another obligation is not to approach the threatened person during the expulsion. This applies to a distance of less than 10 meters. He/she is also obliged to give the address of his/her stay during the expulsion and a contact number. For the obliged person is allowed to take things from their common dwelling which serve the personal needs. Situations may happen when the obliged person forgot some things necessary for his/her business or profession and in that case within 24 hours he/she can apply his/her right to take these things too, but it is possible only once and in the presence of a police officer. The obliged person has the right to be informed in written form from everything what is connected to his/her expulsion. The police officer has the obligation to give these information (Šramel, 2017).

For the threatened person rights and obligations also arise. Regarding the duties of the threatened person they are not explicitly expressed in the Slovak legislation. Nevertheless, we can consider such obligations like to respect the expulsion, keep all conditions of the expulsion and not to disrupt the realisation of the expulsion or to inhibit its performance. Another obligation of the threatened person is to provide only true information to the state authorities. On the proposal of the threatened person the court can prolong the duration of the expulsion. As well as the aggressor even the threatened person has the right to be informed in written form from everything what is connected to his/her expulsion.

The main aim of the institute of expulsion is the protection of the threatened person and to give him/her enough time to consider his/her situation. The aggressor has a right to lodge an objection directly to the police officer on the spot or in a written form within the time limit of 3 days.

\section{Conclusion}

The importance of the education in the field of domestic violence according to the analysed facts and situations is indisputable. The education can serve as a tool of prevention for the future aggressors because they are familiar with the 
consequences of their acts - as well as the legal consequences. To be educated in this area can provide some confidence for the future victims of domestic violence because they know what are they rights in situations like this, how to act and where can they find an assistance. An important finding is that the education is not connected only to the victim or the aggressor, but its importance is at the same level for the law enforcement agencies, social workers or the family members. Their right behaviour and attitude can be helpful for the fast psychical recovery of the victim and it prevents from their secondary victimization. An important step to reduce the domestic violence and the aggressor's actions was the amendment of the Slovak Criminal Code (Criminal Code, Act No. 300/2005) where the criminal offences connected to the domestic violence were tightened and the responsibility was increased.

\section{Acknowledgement}

The contribution was elaborated as a part of the research project APVV 'Možnosti kriminologického a trestnoprávneho riešenia domáceho násilia' [transl.: Possibilities of Criminological and Criminal Law Solutions of Domestic Violence] No. APVV-15-0644. Head of the project - prof. JUDr. Peter Polák, $\mathrm{PhD}$.

\section{References}

Danis, F.S., \& Lockhart, L. (2003). Guest editorial: Domestic violence and social work education: What do we know, what do we need to know? Journal of Social Work Education, 39(2), 215-224.

Faver, C.A., \& Strand, E.B. (2003). Domestic violence and animal cruelty: Untangling the web of abuse. Journal of Social Work Education, 39(2), 237-253.

Klimek, L. (2017). Rozhodnutie Súdneho dvora Európskej únie vo veci C-105/03 - Pupino: postavenie obetí v trestnom konaní - ochrana zranitel'ných osôb - výsluch maloletých svedkov. Kriminologické možnosti riešenia domáceho násilia: zborník príspevkov z vedeckej konferencie s medzinárodnou účast’ou konanej dňa 20. apríla 2017, 375-387.

Noughani, F., \& Mohtashami, J. (2011). Effect of Education on Prevention of Domestic Violence against Women. Iranian Journal of Psychiatry, 6(2), 80-83.

Strémy, T., \& Jurisová, M. (2017). Prevencia domáceho násilia. Kriminologické možnosti riešenia domáceho násilia: zborník príspevkov z vedeckej konferencie s medzinárodnou účast’ou konanej dňa 20. apríla 2017, 125-140.

Svoboda, I. (2017). Mediace konfliktu jako akční pole sociálního pedagoga při prevenmci či řešení domácího násilí. Kriminologické možnosti riešenia domáceho násilia: zborník príspevkov z vedeckej konferencie s medzinárodnou účastou konanej dňa 20. apríla 2017, 396-403.

Šramel, B. (2017). Vykázanie zo spoločného obydlia ako preventívny prostriedok ochrany pred domácim násilím. Kriminologické možnosti riešenia domáceho násilia: zborník 
Papáček, 2019. The Need of Education in the Field of Domestic Violence

príspevkov z vedeckej konferencie s medzinárodnou účast’ou konanej dňa 20. apríla 2017, 263-274.

Tittlová, M. (2016). Consequences of domestic violence against women. Prykarpatskyj jurydyčnyj visnyk: zbirnyk naukovych prac, 5(14), 119-124.

Tittlová, M. (2017). Pojem a znaky domáceho násilia. Kriminologické možnosti riešenia domáceho násilia: zborník príspevkov z vedeckej konferencie s medzinárodnou účastou konanej ď̌a 20. apríla 2017, 18-29.

Tower, L.E. (2003). Domestic violence screening: Education and institutional support correlates. Journal of Social Work Education, 39(2), 479-494. 